\title{
PENERAPAN REWARD UNTUK MENINGKATKAN PRESTASI BELAJAR SISWA
}

\author{
(Penelitian Tindakan Kelas Terhadap Siswa kelas X Akuntansi \\ pada mata pelajaran Ekonomi dan Bisnis \\ Di Sekolah Menengah Kejuruan Negeri 1 Ciruas) \\ Nely Hartika \\ Universitas Banten Jaya \\ Serang-Indonesia \\ nelyhartika@ unbaja.ac.id
}

\begin{abstract}
This study discusses the application of reward in the learning process in order to improve the learning achievement of students of accounting class X in SMK Negeri 1 Ciruas on economic and business subjects aiming to find out how the application of rewards in learning to improve learning achievement. Learning treatment in the form of reward giving is one type of approach in the process of teaching and learning activities that can provide stimulus to students to be more academically achievers in economics and business subjects. Academic achievement is the cognitive ability that begins with enthusiasm and the emergence of student enthusiasm in dealing with the process of teaching and learning activities.This research was conducted at SMK Negeri 1 Ciruas-Serang Banten. The research method used is Classroom Action Research with a qualitative approach. The sample of this study were all students of class X accounting SMK Negeri 1 Ciruas as many as 36 students.The results of this study indicate that there is an increase in learning achievement in economic and business subjects by using a learning approach with the application of rewards in class $X$ Accounting students in SMK Negeri 1 Ciruas.This is evidenced by an increase in learning achievement in economics and business subjects by using a learning approach with the application of rewards in class X Accounting students in SMK Negeri 1 Ciruas. This is evidenced by an increase in the number of students who passed the Minimum completeness criteria by 28 people or $77.78 \%$.
\end{abstract}

Keywords : Reward, Learning Achievement Cognitive Ability.

\section{PENDAHULUAN}

Pendidikan merupakan salah satu aspek penting dalam struktur kehidupan berbangsa dan bernegara di Indonesia. Hal tersebut dikarenakan pendidikan saat ini merupakan salah satu kebutuhan pokok masyarakat selain sandang, pangan, papan, dan kesehatan. Pendidikan juga merupakan representasi dari pembangunan manusia yang tengah menjadi primadona dalam pembangunan nasional selain pembangunan infrastuktur. Pendidikan yang baik di suatu negara mengindikasikan indeks pembangunan manusia yang juga selaras dengan hal tersebut.

Pelaksanaan pendidikan di Indonesia sendiri memiliki dinamika yang kompleks dengan beragam tantangan yang timbul 
dalam penerapan regulasi mengenai pendidikan yang diterbitkan oleh Pemerintah Negara Republik Indonesia. Undang-Undang Republik Indonesia Nomor 20 Tahun 2003 tentang Sistem Pendidikan Nasional sebagai legalstanding bagi pelaksanaan aktivitaspendidikan di Indonesia memiliki posisi yang penting dalam seluruh konsep dan konteks pendidikan dalam berbagai aspek yang menyertainya. Untuk itu seluruh pihak yang terlibat dalam dunia pendidikan di Indonesia diharapkan mampu bersinergi untuk mensukseskan pendidikan di Indonesia.

Komponen bangsa yang terlibat secara langsung maupun tidak langsung dalam aktivitas pelaksanaan pendidikan di Indonesia antara lain, Pemerintah Negara Republik Indonesia melalui Kementerian Pendidikan dan Kebudayaan, Pemerintah Provinsi dan Pemerintah Kabupaten/Kota (Dinas Pendidikan dan Kebudayaan), masyarakat melalui partisipasi masyarakat secara langsung maupun Lembaga Swadaya Masyarakat, private sector (perusahaan/korporasi) melalui program corporate social resposibility, tokohmasyarakat dan tokoh agama dan lain sebagainya. Sinergi dan dan harmonisasi dari berbagai elemen bangsa tersebut diharapkan mampu memajukan kualitas pendidikan di Indonesia secara konsisten dan berkelanjutan.

Harmonisasi dan sinergi antar komponen bangsajuga merupakan aspek yang sangat berpengaruh secara langsung dalam aktivitas pelaksanaan pendidikan di lapangan, dalam hal inisekolah-sekolah, baik sekolah negeri, swasta, hingga homeschooling atau lembaga non-profit yangdiberikan kewenangan oleh otoritas pemerintah untuk menyelenggarakan kegiatan pendidikan. Dalam konteks ini maka, guru dan peserta didik akan menjadi fokus utama pembenahan pendidikan yang pada hakikatnya telah mengalamikemajuan dari berbagai aspek. Partisipasi peserta didik dalam kegiatan belajar mengajar serta kompetensi, kapasitas, kapabilitas dan intergritas guru dalam memberikan pengajaran juga perlu untuk senantiasa diperhatikan.

Pendidikan sendiri merupakan upaya yang dirancang secara khusus (by design) untuk meningkatkan kompetensi seseorang (Anwas, 2014: 24). Sehingga dalam aktivitas belajar mengajar diperlukan suatu kapasitas yang mumpuni dari seorang tenaga pendidik guna menghasilkan mutu pendidikan yang baik. Mutu pendidikan yang baik, dapat dilihat dari sejauh mana kualitas peserta didik yang menjadi objek pendidikan berhasil dalam proses belajar 
mengajar, baik di ruang kelas, maupun di luar kelas.

Konteks mengenai pendidikan sebagaimana diuraikan dalam deskripsi diatas, adalah pemberian informasi yang selengkap mungkin kepada semua pihak dalam suatu sistem organisasi pendidikan (terutama yang akan segera dan langsung terkena dampak perubahan yakni peserta didik) tentang perubahan apa yang akan terjadi serta alasan kuat dan rasional mengapa perubahan tersebut perlu dilakukan. Kiat untuk melaksanakan hal tersebut adalah dengan menyelenggarakan komunikasi yang transparan dan terbuka, baik melalui kegiatan tatap muka, informasi tertulis, diskusi, paparan dan laporan tentang situasi yang tengah dihadapi. Hanya saja perlu dicatat, bahwa kiat ini hanya akan efektif jika alasan utama terjadinya penolakan adalah, penyampaian informasi yang tidak lengkap dan komunikasi yang tidak lancar antara guru dengan para peserta didiknya (Siagian, 2016: 219).

Aktivitas belajar mengajar di sekolah memiliki urgensi vital dalam menciptakan peserta didik yang berkualitas sehingga menghasilkan lulusan yang mampu bersaing dengan masyarakat dalam skala lokal, nasional hingga internasional. Sebagai jenjang terakhir sebelum menghadapi masyarakat umum, peserta didik di jenjang sekolah menengah atas dituntut memiliki kompetensi dan kecakapan yang menunjang untuk menghadapi tantang di dunia kerja maupun di jenjang pendidikan yang lebih tinggi (higher education) yakni pendidikan tinggi di universitas. Untuk itu, guru di jenjang sekolah menengah atas atau kejuruan dan yang setara dengannya harus mampu menciptakan kondisi dimana peserta didik memiliki semangat belajar yang tinggi sehingga akan berimbas pada prestasi belajar peserta didik yang merupakan representasi dari kemampuan peserta didik itu sendiri.

SMK Negeri 1 Ciruas sebagai salah satu entitas yang menyelenggarakan aktivitas pendidikan di bawah Dinas Pendidikan dan Kebudayaan Provinsi Banten merupakan salah satu institusi pendidikan resmi milik Pemerintah yang diamanatkan untuk menyelenggarakan kegiatan pendidikan secara baik. Mempersiapkan generasi penerus bangsa yang mampu bersaing dengan sumber daya manusia dalam lingkup lokal, nasional serta internasional merupakan tanggung jawab yang diemban oleh SMK Negeri 1 Ciruas. Untuk mendukung hal tersebut, tentu pihak SMK Negeri 1 Ciruas harus memperhatikan secara detail mengenai sarana penunjang atau fasilitas sekolah, tenaga pendidik dan kependidikannya serta kerjasamanya dengan masyarakat sekitar. 
Menciptakan kualitas lulusan yang mumpuni selalu diawali dengan proses belajar mengajar yang berlangsung di SMK Negeri 1 Ciruas. Guru bersama-sama dengan para peserta didik harus mampu untuk saling bekerja sama dalam proses belajar mengajar, guru memberikan materi secara menarik dan relevan dengan kapasitas serta kompetensi yang dimilikinya, sedangkan peserta didik diharapkan mampu untuk proaktif di dalam proses kegiatan belajar mengajar. Salah satu hal yang mudah dijadikan sebagai indikator keberhasilan dalam proses belajar mengajar adalah prestasi belajar peserta didik. Prestasi belajar sendiri dapat diasosiasikan melalui kemampuan kognitif, afektif dan psikomotor.

Prestasi belajar siswa merupakan salah satu komponen penilaian yang penting dalam kegiatan belajar mengajar di suatu sekolah. Prestasi belajar akan memberikan gambaran mengenai seberapa jauh peserta didik mampu menyerap materi yang diajarkan oleh guru, baik secara pengetahuan (kognitif), sikap (afektif) maupun secara praktik (psikomotor). Menurut Tu'u (2014: 75), prestasi belajar adalah penguasaan pengetahuan atau keterampilan yang dikembangkan dalam suatu mata pelajaran, lazimnya ditunjukkan dengan nilai tes atau angka yang diberikan oleh guru.

Selain prestasi belajar, komponen penting lainnya dalam proses kegiatan belajar mengajar adalah model pembelajaran, teknik pembelajaran dan atau penerapan stimulus untuk belajar. Fokus dalam penelitian ini adalah pada penerapan stimulus dalam kegiatan belajar mengajar yakni dengan penerapan reward. Secara bahasa reward berasal dari bahasa Inggris yang diartikan sebagai ganjaran, hadiah, upah dan penghargaan (Echols dan Shadily, 2015: 485). Selain itu reward juga dapat diartikan sebagai situasi atau pernyataan lisan yang bisa menghasilkan kepuasan atau menambah kemungkinan suatu perbuatan yang dikerjakan (Caplin, 2015: 436).

Berdasarkan pada pengamatan yang Peneliti lakukan pada kelas X Akuntansi di SMK Negeri 1 Ciruas, terlihat beberapa persoalan yang mengemuka dalam proses belajar mengajar di sekolah tersebut. Salah satu persoalan yang timbul dalam kegiatan belajar mengajar adalah mengenai kondusifitas ruang kelas yang terkadang tidak mampu dikendalikan oleh guru akibat adanya celotehan yang dilontarkan peserta didik saat terjadi situasi yang lucu. Selanjutnya dalam pengamatan penelitian, Peneliti juga melihat rendahnya prestasi belajar yang diraih oleh peserta didik di SMK Negeri 1 Ciruas, hal ini terlihat dari nilai hasil belajar dalam mata pelajaran ekonomi dan bisnis yang masih jauh dari nilai kriteria ketuntasan minimum yang 
merupakan harapan guru serta program studi akuntansi di SMK Negeri 1 Ciruas.

Persoalan sebagaimana disebutkan dalam deskripsi sebelumnya diperburuk dengan monotonnya kegiatan belajar mengajar yang berlangsung di ruang kelas saat mata pelajaran ekonomi dan bisnis diajarkan oleh guru. Kondisi yang monoton tersebut merupakan akibat dari proses pembelajaran yang masih konvensional dimana guru masih menjadi sumber utama informasi mengenai mata pelajaran ekonomi dan bisnis. Dalam konteks ini, para peserta didik di SMK Negeri 1 Ciruas terlihat kurang antusias dalam menghadapi mata pelajaran tersebut karena tidak ada stimulus yang mampu meningkatkan semangat belajar peserta didik.

Kondisi sebagaimana disebutkan dalam uraian di atas mengakibatkan para peserta didik juga tidak pro aktif dalam sesi tanya jawab yang dilontarkan oleh guru. Para peserta didik cenderung diam ketika guru memberikan pertanyaan kepada peserta didik sebagai bagian dari upaya timbal balik atas materi yang disampaikan oleh guru. Hal ini tentu bukan merupakan kondisi yang ideal dalam sebuah kegiatan belajar mengajar. Terlebih dalam kurikulum yang diberlakukan oleh Pemerintah Negara Republik Indonesia yaitu Kurikulum 2013 (K13), seharusnya guru dan peserta didik interaktif ketika melakukan kegiatan belajar mengajar di ruang kelas.

Berbagai fenomena yang mengemukan dalam deskripsi yang telah Peneliti uraikan dalam latar belakang tersebut tentu tidak dapat dibiarkan secara terus menerus. Perlu adanya suatu inovasi dalam belajar agar kegiatan belajar mengajar menjadi lebih interaktif. Berkenaan dengan hal tersebut, teknik pemberian reward dapat dijadikan sebagai salah satu mekanisme yang perlu dicoba oleh guru untuk memberikan stimulus agar peserta didik tidak pasif ketika kegiatan belajar mengajar berlangsung. Sehingga prestasi belajar peserta didik di SMK Negeri 1 Ciruas untuk kelas $\mathrm{X}$ Akuntansi dapat lebih meningkat dari sebelumnya.

Berdasarkan pada fenomena dalam latar belakang yang telah peneliti deskripsikan dalam uraian latar belakang masalah, maka persoalan mengenai prestasi belajar yang timbul dalam pelaksanaan kegiatan belajar mengajar di SMK Negeri 1 Ciruas memiliki urgensi yang penting untuk dilakukan kajian di dalam bidang keilmuan pendidikan akuntansi secara lebih mendalam. Urgensi tersebut memiliki beragam dinamika yang dapat timbul didalam aktivitas belajar mengajar yang dilakukan oleh guru kepada peserta didik. Maka dari itu, Peneliti tertarik untuk melakukan penelitian yang 
berjudul: 'Penerapan Reward Untuk Meningkatakan Prestasi Belajar Siswa kelas X Akuntansi pada mata pelajaran Ekonomi dan Bisnis di SMK Negeri 1 Ciruas"

Inovasi yang dilakukan oleh guru dalam proses belajar mengajar memiliki peran vital yang dapat mengubah persoalan yang timbul ketika proses kegiatan belajar mengajar berlangsung. Inovasi tersebut dapat berupa penerapan model pembelajaran tertentu maupun pendekatan lain yang dianggap sesuai dalam mengatasi berbagai persoalan yang timbul dalam proses belajar mengajar. Diakui atau tidak, saat ini sebagian besar guru di Indonesia masih menerapkan model atau pendekatan pembelajaran yang masih konvensional yaitu ceramah, sehingga proses belajar mengajar yang berlangsung di sebagian besar sekolah di Indonesia masih tergolong sama. Salah satu pendekatan yang dapat dijadikan inovasi oleh guru dalam proses pembelajaran adalah penerapan pemberian reward. Untuk mengetahui secara lebih komprehensif mengenai pendekatan tersebut, berikut Peneliti sajikan deskripsi teori mengenai reward yang dikemukakan oleh para ahli.

Secara etimologi, reward merupakan kata yang diambil dari bahasa inggris, kata tersebut dapat diartikan sebagai ganjaran, hadiah, upah, pahala dan penghargaan (Echols dan Shadily, 2015: 485). Menurut Kamus Besar Bahasa Indonesia, reward merupakan pemberian, hadiah, pemberian kenang-kenangan, penghargaan, penghormatan tentang perpisahan dan cindera mata (kbbi.web.id, 2019). Sedangkan menurut Ngalim Purwanto dalam Kusyairy dan Sukipli (2018: 83), reward merupakan alat untuk mendidik siswa agar dapat merasa senang karena perbuatan atau pekerjaannya mendapat penghargaan.

Pemberian reward dalam proses kegiatan belajar mengajar merupakan peran penting guru dalam melakukan kontrol secara langsung ketika kegiatan belajar siswa dan harus menentukan logika yang penting agar untuk menyampaikan materi pelajaran dengan langkah-langkah dan kemudian memberikan reinforcement (penguatan) segera setelah siswa merespons. Dengan demikian pendekatan reward ini dapat dikatakan sebagai menghubungkan tingkah laku dengan konsekuensi terhadap hasil belajar siswa.

Reward merupakan salah satu alat atau media dalam pendidikan, secara umum, reward dikategorikan sebagai alat untuk mendidik anak agar dapat merasa senang, reward juga dapat diartikan sebagai penghargaan atau dampak yang diperoleh dari perbuatan atau pekerjaan 
yang baik. Selanjutnya reward diterapkan dalam pendidikan sebagai upaya meningkatkan semangat atau motivasi belajar siswa untuk menjadi lebih giat guna memperbaiki prestasi yang telah dicapai (Purwanto, 2017: 182).

Pada dasarnya reward memang alat yang berguna untuk meningkatkan motivasi belajar siswa guna mencapai prestasi belajar belajar yang lebih tinggi (lebih baik), maka penerapan reward dalam belajar sangat diperlukan. Sejalan dengan penjelasan Kenneth $H$. Hover dalam Hamalik (2015: 163-165), berdasarkan penelitiannya dalam rangka menciptakan self motivation dan self discilpline pada siswa reward merupakan "pujian atau ganjaran yang akan datang dari luar (external reward) kadang-kadang diperlukan dan cukup efektif untuk merangsang minat yang sebenarnya".

Menurut Sriyanti dkk., yang dikutip oleh Yana, Hajidin dan Safiah (2016: 13), mengemukakan bahwa reward digunakan oleh guru sebagai bentuk penguatan, stimulus dalam mendidik siswa. Dalam teori pembelajaran istilah tersebut dikenal sebagai law of effect perilaku yang bersifat menyenangkan cenderung untuk diulang atau dipertahankan, sedangkan perilaku yang menimbulkan efek tidak menyenangkan cenderung untuk ditinggalkan atau tidak diulang. Maksud dari pendapat tersebut adalah bahwa reward memiliki kecenderungan sebagai aktivitas atau perilaku yang menyenangkan dari guru kepada peserta didik dalam sebuah proses kegiatan belajar mengajar. Sehingga reward layak untuk digunakan sebagai salah satu teknik pendekatan dalam sebuah proses pembelajaran.

Proses pelaksanaan kegiatan belajar mengajar melalui penerapan reward dapat dijadikan sebagai tahapan yang merupakan penjabaran dari sebuah kebijakan yang bersifat abstrak dan sangat umum ke dalam kebijakan atau tindakan yang lebih bersifat manajerial dan operasional (Mulyadi, 2016: 13). Artinya guru menerapkan suatu kebijakan yang bersifat di luar dari sekedar penilaian yang merupakan aktivitas yang lazim dilakukan dalam suatu proses pembelajaran. Dengan menerapkan reward operasionalisasi proses pembelajaran akan memiliki diversifikasi (keanekaragaman) jenis dari proses pembelajaran yang dapat menjadi pengalaman baru bagi guru yang bersangkutan dengan para peserta didiknya

Berdasarkan pada beberapa pendapat yang dikemukakan oleh para ahli dalam deskripsi teori di atas, maka dapat disimpulkan bahwa reward merupakan salah satu pendekatan belajar yang dapat dilakukan oleh guru guna menstimulus 
tingkat keaktifan peserta didik ketika proses kegiatan belajar mengajar berlangsung. Penerapan pemberian reward kepada peserta didik dapat dilakukan melalui hal-hal kecil seperti memberikan tepuk tangan kepada peserta didik yang mampu menjawab pertanyaan dari guru atau dapat pula diberikan hadiah berupa benda penunjang kegiatan belajar seperti ballpoint, buku dan lain sebagainya. Sehingga peserta didik lain akan terpacu ketika guru mengajukan pertanyaan lain atau mengajak interaksi dalam bentuk yang berbeda.

Prestasi diambil dari bahasa belanda yang artintya hasil dari sebuah usaha, prestasi adalah sebuah hasil atau keberhasilah yang dicapai oleh seseorang setelah melakukan suatu kegiatan baik dalam pendidikan maupun pekerjaan. Menurut Kmus Besar Bahasa Indonesia yang dinamakan Prestasi adalah hasil yang telah dicapai, dilakukan, dilaksanakan dan sebagainya. sedangkan belajar merupakan suatu proses mencari ilmu pengetahuan dari yang tidak tahu menjadi tahu (kbbi.web.id, 2019). Belajar adalah suatu proses usaha yang dilakukan individu untuk memperoleh suatu perubahan tingkah laku yang baru keseluruhan, sebagai hasil pengalamanindividu itu sendiri dalam interaksinya dengan lingkungan. Kesimpulan yang bisa diambil dari kedua pengertian di atas, bahwa pada prinsipnya, belajar adalah perubahan dari diri seseorang.

Prestasi belajar dapat diartikan sebagai perilaku peserta didik yang terjadi setelah adanya proses belajar mengajar yang sesuai dengan tujuan pendidikan. Menurut Mohammad Surya dalam (Donny 2017: 43) mengemukakan bahwa prestasi belajar adalah suatu upaya yang mencakup penguasaan kognitif, afektif konatif dan motorik melalui proses interaksi antara individu dan lingkungan yang terjadi sebagai hasilatau akibat pembelajaran.

Berbeda dengan pendapat R.M. Gagne yang dikutip juga oleh Donny (2017: 44), mengungkapkan bahwa prestasi belajar merupakan human capabilities (kecakapan manusiawi) yang meliputi verbal, kecakapan intelektual (diskriminasi, konsep konkret, konsep abstrak dan aturan yang lebih tinggi), stategi kognitif, sikap dan kecakapan motorik. Secara spesifik Donny (2017: 44) menyimpulkan bahwa prestasi belajar adalah kemampuan yang meliputi beberapa ranah psikologi (kognitif, afektif, dan psikomotor) yang berubah akibat pengalaman dan proses belajar peserta didik. Prestasi belajar dapat dilihat melalui perubahan prilaku siswa sebelum dan sesudah belajar. Hal ini dapat dijadikan sebagai tolok ukur berhasil atau tidaknya kegiatan belajar dan mengajar. 
Hasil yang diperoleh melalui aktivitas belajar adalah nilai yaitu berupa angkaangka yang diperoleh melalui ulangan atau tes yang dilakukan sebagai aktivitas akhir belajar mengajar. Angka-angka ini ditempatkan dalam buku rapor sesuaidengan mata pelajaran yang diprogramkan dalam kurikulum (Donny 2017: 123).

Prestasi belajar sesungguhnya merupakan pencapaian peserta didik atas keberhasilannya menghadapi suatu proses pembelajaran. Kegagalan dalam pelaksanaan suatu jenis pembelajaran dipengaruhi oleh dua hal, yakni ketidakmampuan peserta didik terutama sebagai anggota dalam proses pembelajaran di dalam kelas pada bidang wawasan keilmuan (science), rendahnya penguasaan keterampilan (skill) dan tidak berkembangnya pengalaman-pengalaman pengetahuan (knowledge) (Makmur, 2015: 227). Faktor lainnya adalah ketidakberdayaan seorang peserta didik baik sebagai anggota proses pembelajaran di ruang kelas, maupun sebagai entitas pelajar secara umum. Kondisi tersebut tentu harus dapat dihindari oleh guru guna melancarkan aktivitas pembelajaran yang diampunya.

Berdasarkan uraian diatas dapat disimpulkan bahwa pengertian prestasi belajar dari seseorang dapat dilihat dari perilakunya, baik perilaku dalam bentuk penguasaan pengetahuan, keterampilan berfikir maupun keterampilan motorik. Di sekolah, hasil belajar ini dapat dilihat dari penguasaan siswa akan mata pelajaran yang ditempuhnya. Prestasi belajar adalah hasil usaha siswa dalam bentuk angka yang menunjukan perubahan tingkah laku dalam proses belajar.

\section{METODE PENELITIAN}

Berdasarkan pada tujuan penelitian, maka penelitian ini dapat dikategorikan sebagai penelitian tindakan kelas (PTK) atau Classroom Action Research (CAR). Terdapat beberapa macam desain penelitian model dalam penelitian tindakan kelas (PTK) yakni, Kurt Lewin, Kemmis dan McTaggart serta Elliot. Penelitian ini menggunakan desain model penelitian tindakan kelas yang diciptakan oleh Kemmis dan MCTaggart, hal tersebut dikarenakan desain dalam penelitian ini dianggap mudah dalam prosedur penerapannya, namun tetap memiliki kredibilitas yang baik untuk suatu karya ilmiah yang bersifat empiris dan akademis. Alur pelaksanaan penelitian tindakan kelas model Kemmis dan McTaggart dapat dilihat dalam gambar di bawah ini : 


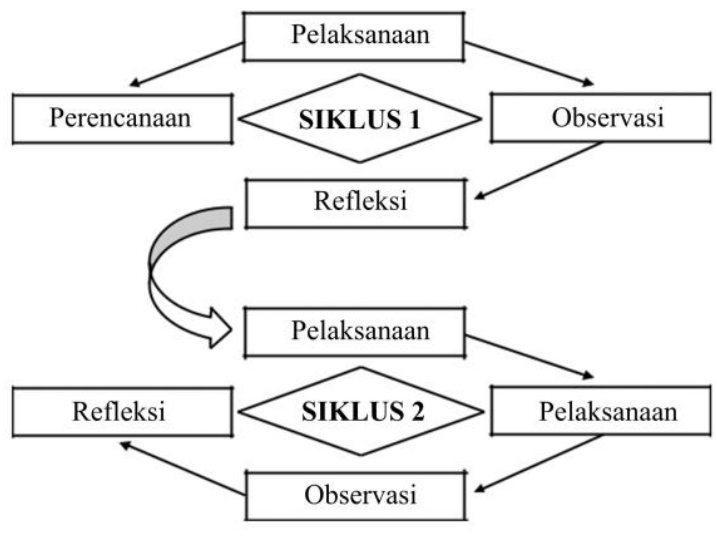

Sumber: (Arikunto, dkk., 2015: 42)

\section{Gambar 1 . Alur Pelaksanaan PTK Model Kemmis dan McTaggart}

Pembelajaran pada umumnya, guru masih menggunakan metode cerama, yaitu menyampaikan materi ajar hanya dengan melisankan terus-menerus. Peserta didik atau siswa dibiarkan mendengarkan penjelasan guru yang hanya menyampaikan melalui lisan saja. Banyak siswa yang merasa tidak tertarik dengan penjelasan guru, akibatnya siswa menjadi mengantuk. Apa yang disampaikan guru tidak masuk ke otak siswa untuk diproses menjadi pengetahuan (Arikunto dkk., 2015: 6).

Penelitian tindakan kelas (PTK) memiliki tujuan untuk memperbaiki kualitas praktik pembelajaran di dalam kelas dan perilaku siswa di kelas. Secara umum, terdapat empat tahapan yang harus dilewati untuk melakukan penelitian dengan model penelitian tindakan kelas (PTK), yaitu : perencanaan, pelaksanaan, observasi dan refleksi (Arikunto, 2015:
42). Keempat tahapan tersebut merupakan suatu unsur dalam membentuk sebuah siklus, yaitu dengan satu putaran kegiatan secara beruntun untuk selanjutnya kembali ke tahap pertama.

\section{PEMBAHASAN}

Prestasi belajar peserta didik dengan menggunakan model pendekatan belajar dengan penerapan pemberian reward dilihat dari rata-rata nilai setiap tindakan telah terjadi peningkatan, hasil tes siklus 1 dapat diketahui bahwa dari 36 siswa, nilai siswa yang berada di bawah rata-rata berdasarkan pada hasil skor hasil pretest dan posttest, prestasi belajar siswa yang diukur melalui kemampuan kognitif pada siklus 1 masih harus ditingkatkan, karena masih banyak nilai siswa yang berada di bawah rata-rata yaitu 28 siswa nilai skor pretest dan posttest masuk dalam kategori rendah dengan persentase sebanyak $77,78 \%$. Sementara itu hanya ada 8 peserta didik dengan nilai kognitif yang masuk dalam kategori sedang yakni dengan persentasi sebanyak 22,22\%. Rata-rata nilai pre-test pada siklus 1 adalah sebesar 49 sedangkan untuk nilai post-test rataratanya adalah sebesar 65 .

Berbeda dengan hasil yang dicapai dalam siklus tindakan 1, pada siklus tindakan 2, merujuk pada hasil skor kemampuan kognitif sebagai representasi 
dari prestasi belajar peserta didik yang diukur dengan kemampuan kognitif sudah mengalami perbaikan, hasil yang diperoleh adalah 8 orang masih dikategorikan rendah nilai prestasi belajarnya, sedangkan sebanyak 20 siswa telah masuk dalam kategori yang sedang, dan sisanya sebanyak 8 orang termasuk dalam kategori skor perolehan prestasi belajar yang tiggi. Rata-rata nilai pre-test pada siklus 2 adalah sebesar 70, sedangkan untuk nilai post-test rata-ratanya adalah sebesar 76,9. Untuk mempermudah hasil penelitian, berikut peneliti sajikan tabel 1 yang merupakan hasil perhitungan tingkat kelulusan peserta didik kelas X akuntansi di SMK Negeri 1 Ciruas pada mata pelajaran ekonomi dan bisnis:

Tabel 1 Hasil Perhitungan Prestasi Belajar Menggunakan Pene rapan Re ward

\begin{tabular}{lccl}
\hline No & $\begin{array}{l}\text { Memenuhi } \\
\text { KKM }\end{array}$ & $\begin{array}{l}\text { Belum } \\
\text { Memenuhi } \\
\text { KKM }\end{array}$ & $\begin{array}{l}\text { Rata- } \\
\text { Rata }\end{array}$ \\
\hline Siklus I & & & \\
Pre test & 0 siswa & 36 siswa & 49 \\
& $0 \%$ & $100 \%$ & \\
Post test & 8 siswa & 28 siswa & 70 \\
& $22,22 \%$ & $77,78 \%$ & \\
Siklus II & & & \\
Pre test & 18 siswa & 18 siswa & 70 \\
& $50 \%$ & $50 \%$ & \\
Post test & 28 siswa & 8 siswa & 76,9 \\
\multicolumn{5}{c}{$77,78 \%$} & $22,22 \%$ \\
\hline Sumber : Hasil Penelitian, 2019
\end{tabular}

Sumber : Hasil Penelitian, 2019

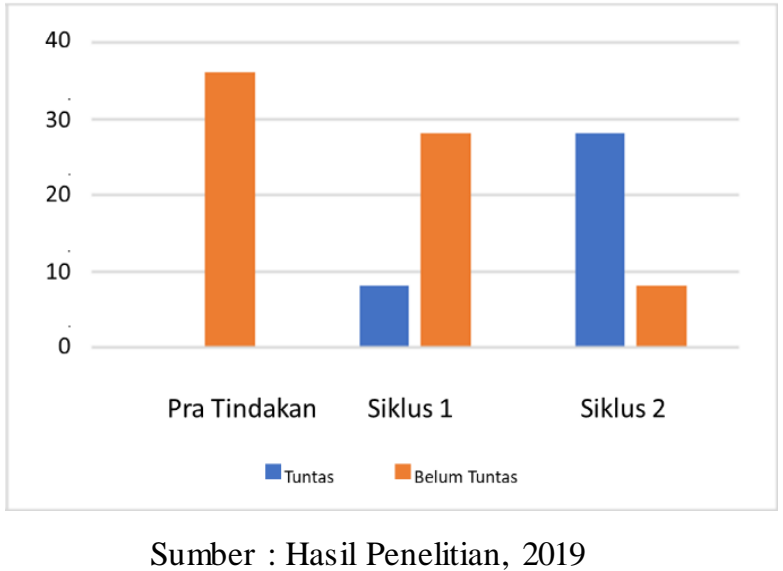

Gambar 2

Histogram Ketuntasan Kriteria Minimum Pembelajaran berupa penerapan reward di kelas $\mathrm{X}$ Akuntansi di SMK Negeri 1 Ciruas dalam mata pelajaran ekonomi dan bisnis untuk mempelajari materi pembelajaran evaluasi masalahmasalah ekonomi klasik dan modern dapat dilihat dalam poin-poin sebagai berikut : Peneliti mengamati bahwa peserta didik cenderung lebih antusias dalam menerima materi setelah mereka diberi tahu akan memperoleh reward dari guru apabila mampu proaktif dan meningkatkan prestasi belajarnya dalam mata pelajaran ekonomi dan bisnis. Suasana di dalam kelas terlihat lebih kondusif karena para peserta didik lebih banyak yang memperhatikan guru ketika memberikan materi pelajaran. 


\section{KESIMPULAN}

Berdasarkan pada hasil penelitian dan pembahasan yang telah diuraikan sebelumnya, maka dapat disimpulkan bahwa :

1. Terdapat peningkatan prestasi belajar dalam mata pelajaran ekonomi danbisnis dengan menggunakan pendekatan belajar dengan penerapan reward pada siswa kelas X Akuntansi di SMK Negeri 1 Ciruas tahun ajaran 2019/2020. Hal tersebut dibuktikan dengan adanya peningkatan jumlah siswa yang lulus Kriteria Ketuntasan Minimum dimana dalam siklus 1 hanya ada 8 siswa atau 22,22\% yang memenuhi KKM, selanjutnya dalam siklus 2 sebanyak 28 siswa atau $77,78 \%$ telah berhasil memenuhi KKM, artinya terjadi peningkatan prestasi belajar sebesar 55,56\%;

2. Penerapan reward dalam proses pembelajaran berhasil meningkatkan antusiasme siswa dalam merespon pertanyaan yang diajukan oleh guru, karena siswa mengetahui bahwa apabila berhasil menjawab pertanyaan dari guru siswa akan memperoleh poin yang diakumulasikan untuk selanjutnya diberi hadiah (reward) di akhir pertemuan.

\section{SARAN}

Berdasarkan hasil analisa, pembahasan dan kesimpulan yang telah dilakukan maka, berikut ini ada beberapa hal yang disarankan, yaitu sebagai berikut:

Sebaiknya guru juga memberikan kesempatan kepada siswa untuk aktif dalam bertanya pada saat pembelajaran tentang materi yang kurang dimengerti.

1. Guru mata pelajaran ekonomi dan bisnis dapat menerapkan model pembelajaran yang bervariasi dan interaktif sehingga prestasi belajar siswa pada mata pelajaran ekonomi dan bisnis dapat meningkat.

2. Guru mata pelajaran Ekonomi dan bisnis untuk meningkatkan kemampuan dan keterampilan penguasaan model pembelajaran untuk meningkatkan prestasi belajar siswa.

\section{DAFTAR PUSTAKA}

Anwas, Oos M. 2014. Pemberdayaan Masyarakat di Era Global. Bandung: Alfabeta.

Arikunto, Suharsimi. Suhardjono dan Supardi. 2015. Penelitian Tindakan Kelas. Edisi Revisi. Jakarta: PT. Bumi Aksara.

Caplin, C.P. 2015. Kamus Lengkap Psikologi. Terjemahan Kartini Kartono Edisi Ke-7. Jakarta: PT. Rajawali. 
Donny, Juni Priansa. 2017. Pengembangan Strategi dan Model Pembelajaran ISBN. Bandung: CV. Pustaka Setia.

Echols, John M. dan Hassan Shadily. 2015. Kamus Inggris-Indonesia. Edisi yang diperbaharui. Jakarta: PT. Gramedia Pustaka Utama.

Hamalik, Oemar. 2015. Kurikulum Pembelajaran. Jakarta: PT. Bumi Aksara.

Makmur. 2015. Efektivitas Kebijakan Kelembagaan Pengawasan. Cetakan Kedua. Bandung: Refika Aditama.

Mulyadi, Deddy. 2016. Studi Kebijakan Publik dan Pelayanan Publik. Edisi Revisi. Bandung : Alfabeta.

Purwanto, Ngalim. 2017. Psikologi Pendidikan. Bandung: PT. Remaja Rosdakarya.

Siagian, Sondang P. 2016. Kiat Meningkatkan Produktivitas Kerja. Cetakan Kedua. Jakarta: Rineka Cipta.

Tu'u, T. 2014. Peran Disiplin PadaPerilaku dan Prestasi Siswa. Jakarta: PT. Gramedia Widiasarana.

Kusyairy, Umi dan Sukipli. 2018. Meningkatkan Hasil Belajar Peserta Didik Melalui Pemberian Reward and Punishment. Jurnal Pendidikan Fisika. Vol. 6 No. 2. ISSN: 23555785. Makassar: Universitas Islam Negeri Alauddin.

Yana, Dewi, Hajidin dan Intan Safiah. 2016. Pemberian Reward dan Punishment Sebagai Upaya Meningkatkan Prestasi Siswa Kelas $V$ di SDN Lhokseumawe. Jurnal Ilmiah Pendidikan Guru Sekolah
Dasar. Vol. 1 No. 2. Aceh: Universitas Syiah Kuala.

Undang-Undang Republik Indonesia Nomor 20 Tahun 2003. Tentang Sistem Pendidikan Nasional. Jakarta: Tambahan Lembaran Negara Republik Indonesia Nomor 4301.

Kamus Besar Bahasa Indonesia. 2019. Hadiah. Kamus Versi Daring/Online.

https://kbbi.web.id/hadiah, diakses pada 21 Agustus 2019 (07.43 WIB). 